\title{
Pathogenesis of a Newly Isolated Rat Virus in Newborn and Juvenile Rats
}

\author{
Ken-ichi YAGAMI, Tominaga FUKAZAWA, \\ Yoshihiro SUGIYAMA, and Keiji FUJII*
}

\begin{abstract}
Laboratory Animal Research Center, and * Department of Pathology, Institute of Basic Medical Sciences, University of Tsukuba, Tsukuba-shi, Ibaraki 305, Japan
\end{abstract}

(Received 26 December 1990/Accepted 26 March 1991)

\begin{abstract}
The pathogenesis of the UT-1 strain, a newly isolated rat virus (RV), in juvenile and newborn rats was examined. Intracerebrally (ic) inoculated newborns developed severe pantropic infections resulting in emaciation, stunted growth, diarrhea, dehydration and icterus, and died 13 to 15 days after the inoculation. Newborns inoculated intraperitoneally (ip) developed similar, but milder diseases. The virus replicated in all the organs tested, which was followed by severe viremia. Histopathologically, diffuse vacuolation and necrosis of the hepatocytes were observed in the liver. Juvenile rats inoculated with the virus showed neither clinical signs nor histopathologic lesions, although viral recovery and antibody production were observed. Thus, we conclude that the UT- 1 strain of RV caused asymptomatic infections in juvenile rats, and fatal infections with hepatic lesions in newborn rats. KEY WORDS : jovenile rat, newborn rat, pathogenesis, rat virus
\end{abstract}

Rat virus (RV), a member of the family Parvoviridae, is one of the common viruses in laboratory rat colonies and often causes asymptomatic infections in adult rats, and severe diseases in fetal and newborn rats $[1,7$, 11, 14-16]. Little attention, however, has been paid to the $R V$ infection in laboratory rat colonies in Japan, since there has been no information about it. We have isolated new $R V$ strains in Japan from asymptomatic adult rats and have found the Japanese isolates to have hemagglutination patterns differing from those of the RV-13 prototype strain [5] .

In this study, newborn and juvenile rats were experimentally infected with one of the newly isolated strains of RV, UT-1 strain, to determine its pathogenicity.

\section{Materials and Methods}

Virus : The UT-1 strain of RV was used. It was isolated from the spleen of an asymptomatic adult rat [5] and purified by plaquecloning in rat embryo (RE) cells. The virus stocks passaged 10 times in RE cells were used for following animal experiments.

Animals : Specific pathogen-free outbred Slc : Wistar rats (Japan SLC Co. Ltd.) were used. They were maintained in a barrier sustained animal room of our facility, and given a commercial diet (NMF : Oriental Yeast Co. Ltd.) and autoclaved water ad libitum. These rats were checked serologically before inoculation with $\mathrm{RV}$, and proved to be consistently seronegative to common murine viruses including RV.

Animal experiments : Six-week-old female juveniles, and 2-day-old newborn rats were inoculated with UT-1 strain ic or ip. The optimal concentration of the virus suspension for the inoculation was prepared with Eagle's minimum essential medium (MEM). The inoculum for ic infection contained $5 \times 10^{4} \mathrm{TCID}_{50} / 5 \mu \mathrm{l}$ of the virus and that for ip $5 \times 10^{5} \mathrm{TCID}_{50} / 50$ $\mu 1$, respectively. Juvenile rats were lightly anesthetized with ether before the ic inoculation. The infected rats were kept in a negative flow isolator (GERM FREE Laboratories, 
Inc., USA), and inspected daily for clinical signs. At the various stages of infection, rats were sacrificed by bleeding from a cardiac puncture after deep anesthesia with ether. The brain, lung, liver, spleen and kidneys from the infected rats were divided into two pieces, and one was offered for virus recovery and the other for histopathological examination.

In the second experiment, lower doses of the virus $\left(5 \times 10^{1}\right.$ TCID $_{50} / 5 \mu 1$ for ic inoculation and $5 \times 10^{2} \operatorname{TCID}_{50} / 50 \mu \mathrm{l}$ for ip) were inoculated into newborn rats. Several organs collected at the various stages of infection were examined for virus recovery.

Virus recovery: Each organ taken from three animals were pooled, suspended in MEM to be $5 \%$ homogenate and centrifuged at 3,000 $\mathrm{rpm}$ for $10 \mathrm{~min}$. Each $200 \mu \mathrm{l}$ of the supernatant was inoculated into $\mathrm{RE}$ cell culture which had been seeded on 24-wells microplate (Falcon) $2 \mathrm{hr}$ before. After 6 days culture, the hemagglutination (HA) activity of the culture fluid for the guinea pig erythrocyte was examined. When HA activity was not seen even in the second blind passage, the specimen was determined to be negative for virus recovery.

Infectivity titration was carried out for the HA-positive specimens. A serial $10-$ fold dilution of the tissue homogenate was made with MEM, and $100 \mu \mathrm{l}$ of the suspension was inoculated into RE cell culture in the 96-wells microplate. Virus growth was examined by hemadsorption to guinea pig erythrocyte after 6 days of culture. The infectivity titer was expressed as $50 \%$ of the tissue culture infectious dose $\left(\right.$ TCID $_{50}$ ) by the method of Reed and Muench [20].

Enzyme-linked immunosorbent assay (ELI SA) : To detect the serum antibody to the $\mathrm{RV}$ at each stage of infection, an ELISA was applied by the procedure previously described $[5,6]$.

Histological and immunohistological observation : The brain, lung, liver, spleen and kidneys from affected animals at various stages of the RV infection were fixed in a buffered $10 \%$ formalin, and paraffin sections were stained with hematoxylin and eosin $(\mathrm{H}-\mathrm{E})$. The sections were also stained with anti-RV guinea pig serum and peroxidase-conjugated anti-guinea pig immunoglobulins (Cappel, USA). The optimal concentrations of anti-RV serum and conjugated anti-guinea pig immunoglobulins were mounted on the sections pre-treated with $0.5 \% \mathrm{H}_{2} \mathrm{O}_{2}$ in $80 \%$ methanol for $30 \mathrm{~min}$. The sections were visualized with a substrate solution consisting of $10 \mathrm{mg}$ of 3,3 diminobenzidine and $10 \mu \mathrm{l}$ of a $30 \% \mathrm{H}_{2} \mathrm{O}_{2}$ solution in 100 $\mathrm{ml}$ of $10 \mathrm{mM}$ tris- $\mathrm{HCl}$ buffer (pH 7.4), and then counterstained with hematoxylin.

\section{Results}

Clinical signs : Newborn rats infected ic developed emaciation, stunted growth, diarrhea, dehydration and icterus from 10 days postinoculation (pi), and all animalls died at 13 to 15 days pi. All newborns infected ip also developed slight emaciation and stunted growth, while only one animal died. However, the juvenile rats infected either ic or ip showed no clinical signs for 15 days of observation, and all animals survived (Table 1).

Antibody response : The antibody response of the infected newborns and juveniles, was examined by the ELISA (Fig. 1). The antibody was first detected 5 days after the inoculation in juveniles infected ic as well as ip, and the titer increased rapidly through 15 days pi. In newborns inoculated either ic or ip, antibody

Table 1. Mortality of newborn and juvenile rats inoculated with UT-1 strain of RV

\begin{tabular}{ccccc}
\hline $\begin{array}{c}\text { Rats } \\
\text { Age })\end{array}$ & $\begin{array}{c}\text { Inoculation } \\
\text { routes }\end{array}$ & $\begin{array}{c}\text { Virus dose } \\
\left(\text { TCID }_{50}\right)\end{array}$ & $\begin{array}{c}\text { No. of death } / \\
\text { No. of inoculated }\end{array}$ & Days at death \\
\hline $\begin{array}{c}\text { Newborn } \\
\text { (2-day-old) }\end{array}$ & ic & $5 \times 10^{4}$ & $6 / 6$ & $13-15$ \\
& ip & $5 \times 10^{5}$ & $1 / 5$ & 15 \\
Juvenile & ic & $5 \times 10^{4}$ & $0 / 3$ & - \\
(6-week-old) & ip & $5 \times 10^{5}$ & $0 / 3$ & - \\
\hline
\end{tabular}

Rats were observed until 15 days post inoculation. 


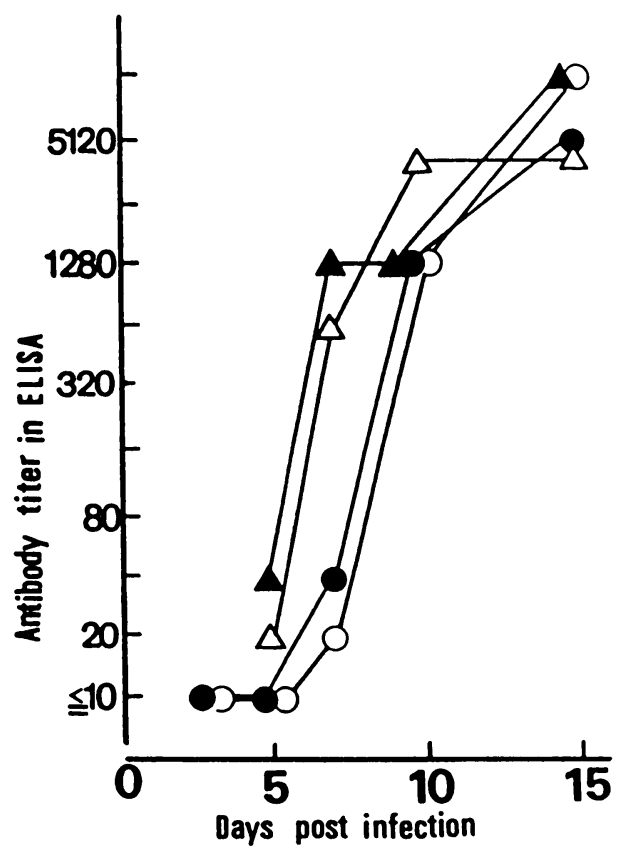

Fig. 1. Antibody responses in juvenile and newborn rats inoculated with the UT-1 strain. Rats were inoculated ic with $5 \times 10^{4}$ TCID $_{50}$ (newborn; - - , and juvenile ; $-\triangle-$ ), or ip with $5 \times 10^{5} \operatorname{TCID}_{50}$ (newborn; - - and juvenile ; $-\mathbf{\Delta}-$ ). Each point gives geometric mean titer of 3 juveniles, or the titer of pooled serum from 3 newborns. was detected on day 7 , and reached the same level $(5,120$ to 10,240$)$ as in juveniles on 15 days pi.

Virus recovery: Three infected juvenile rats that continued to be asymptomatic were sacrificed at 15 days after the inoculation, and virus recoveries from the brain, lung, liver, spleen, kidneys and serum were checked. The organs from which the virus was recovered, were limited to the spleen in ic inoculated rats, and to the lung, spleen and kidneys in ip inoculated ones (Table 2). Furthermore, their viral titer was low.

In the infected newborns, virus recovery was examined at various stages of the infection (Fig. 2). The infectious virus was recovered from all the organs of the infected newborns. Both the infected newborns inoculated ic and ip were viremic at 3 days pi with a higher dose of the virus, and at 5 days pi with a lower dose. The viremia continued for 15 days, until the observation terminated. The infective titers of all organs consistently reached maximum at 7 to 10 days pi and decreased at 15 days pi. All through the observation periods, the infectivity titers continued to be higher in every organ from newborns inoculated with high dose of the virus rather than with low dose.

Histopathology and immunohistochemistry: Severe histopathological changes were

Table 2. Distribution of histopathological lesion and virus antigen and infective virus recovery in newborn and juvenile rats inoculated ic or ip with UT-1 strain

\begin{tabular}{|c|c|c|c|c|c|}
\hline \multirow[t]{2}{*}{ Organs } & \multicolumn{3}{|c|}{ Newborns } & \multicolumn{2}{|c|}{ Juveniles } \\
\hline & ic & & ip & ic & ip \\
\hline Liver & $+++/+++/++^{*}$ & ++1 & $++/++$ & $-1-1-$ & $-1-1-$ \\
\hline Brain & $++1++1++$ & +1 & $++1++$ & $-1-1-$ & $-1-1-$ \\
\hline Kidneys & $++/++t++$ & +1 & $++1++$ & $-1-1-$ & $-1-1+$ \\
\hline Spleen & $++1++$ & -1 & $++1++$ & $-/-1+$ & $-1-1+$ \\
\hline Lung & $-/ \quad+1++$ & -1 & $++/++$ & $-1-1-$ & $-1-1+$ \\
\hline
\end{tabular}

The results at 15 days after inoculation are shown. $\quad{ }^{*}$ Histopathological lesion/virus antigen by immunoperoxidase method/virus recovery. Degree of lesion: - negative ; + slight $;++$ moderate $;+++$ severe. Virus antigen : - negative ; + small number $;++$ moderate number $;+++$ large number Virus recovery :- negative ; $+<10^{3} \mathrm{TCID}_{50} / 100 \mu 1 ;++\geqq 10^{3} \mathrm{TCID}_{50} / 100 \mu 1$ 

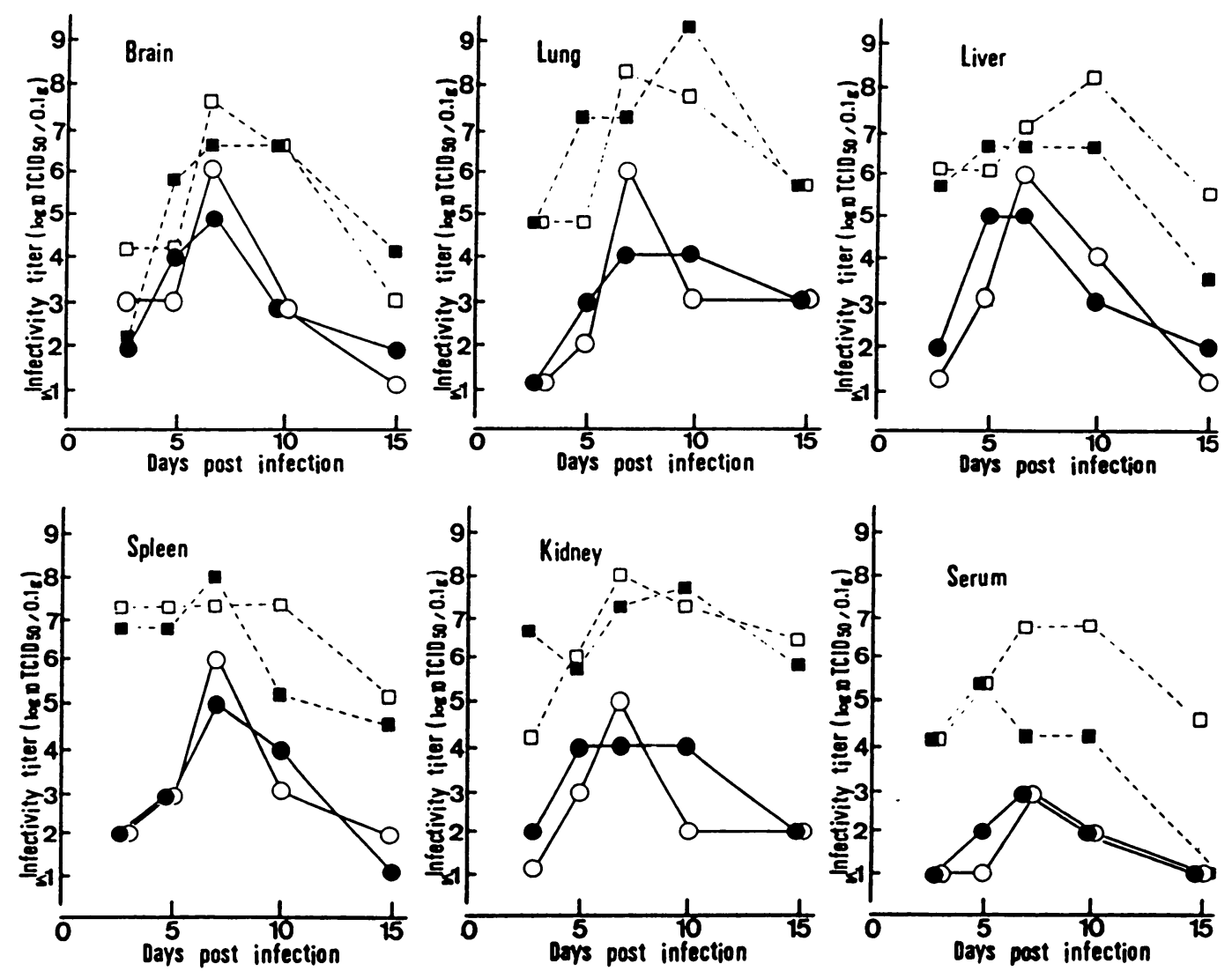

Fig. 2. Changes in viral infectivity titer of the organs in newborn rats infected with high or low dose of the UT- 1 strain. Newborns were inoculated with high dose $\left(5 \times 10^{4}\right.$ TCID $_{50}$ for ic route; $-\square-$, and $5 \times 10^{5}$ TCID $_{50}$ for ip route; $\left.-\square-\right)$, or low dose $\left(5 \times 10^{1}\right.$ TCID $_{50}$ for ic; $-\bigcirc-$, and $5 \times 10^{2}$ TCID $_{50}$ for ip; - - ). Each organ from three animals was pooled and examined for viral infectivity titer.

observed in the liver of newborn rats infected ic or ip with a high dose of virus, and mild lesions were observed also in the brain, kidneys and spleen. The distribution of histopathological lesions and virus antigen and recovery of infectious virus are summarized in Table 2.

In the liver, the most prominent lesions were diffuse vacuolation and necrosis of hepatocytes accompanied by marked lymphoid cell infiltration in Glisson's sheath at 10 and 15 days pi (Fig. $3 \mathrm{~A}$ ). Infiltration of the lymphocytes and plasmocytes in Glisson's sheath, increased number of Kupffer's cells in the sinusoid, and the appearance of mitotic hepatocytes were also observed at 5 to 15 days pi. These changes in the ic inoculated newborns were severer than those in the ip-inoculated newborns. Viral antigen was markedly detected in nuclei of hepatocytes, and slightly in granules of cytoplasm at 3 to 15 days pi (Fig. 3B). However, the antigen-positive site was not correlated to the severity of the lesions in the liver.

Brain lesions were several focal hemorrhages in the cerebellum at 7 to 15 days pi. The viral antigen was localized in the granular layer of the cerebellum at 5 to 15 days pi (Figs. $3 \mathrm{C}$ and $3 \mathrm{D})$.

Kidney lesions represented infiltration of lymphoid cells in the renal cortex or subcapsule at 10 to 15 days pi. The antigen was markedly found in nuclei of epithelial cells in the renal tubules and the collecting tubules (Figs. $3 \mathrm{E}$ 
and $3 \mathrm{~F}$ ).

In the spleen, mild subcapsular hemorrhage was observed in the ic-inoculated newborns, but not in the ip-inoculated newborns. The viral antigen was detected in various kinds of cells at 3 to 15 days pi, being prominent especially at the early stages of infection ( 3 to 5 days pi) in both the ic- and ip-inoculated newborns. There were no significant lesions in the lung, although the antigen was detected in endothelial cells of alveolar capillaries at 3 to 15 days pi. The feature of the lesions observed in newborn liver, brain, kidneys or spleen was same regardless of the virus dose inoculated, although the lesions of the newborns infected with a lower dose of the virus were milder.

In the juvenile rats, neither lesions nor viral antigen were observed in any organs at 15 days pi.

\section{Discussion}

In the present study, the newly isolated UT-1 strain of RV definitely caused severe pantropic infections in newborn rats and asymptomatic infections in juvenile rats. In particular, the ic-inoculated newborns developed fatal signs and symptoms which were microscopically characterized by diffuse vacuolation and necrosis of the hepatocytes approximately 2 weeks after the inoculation.

Concerning the pathogenicity of $\mathrm{RV}$, several studies $[9,12,13]$ have shown that the infection induced fetal and neonatal abnormalities by viral replication in the specific cell populations at $S$-phase which were actively proliferating during the course of a fetal development. On the other hand, mature rats are usually resistant to RV because their tissues are mitotically quiescent. Some strains of RV usually cause asymptomatic infections in adult rats, except immunosuppressive rats $[1,16]$ which developed hemorrhagic encephalopathy.

The pathogenicity of RV, however, may be influenced by genetic factors of the virus as well as by virus replication in the cell populations at S-phase. For instance, certain strains of RV have been isolated from naturally occurring lethal diseases of young adult rats characterized by hemorrhage and necrosis of the brain, testis and epididymides [3]. Besides, it has been shown that parvoviruses in general easily develop variant types which have diffe- rent HA pattern, host range, pathogenicity and antigenicity depending on the altered viral genome. Senda, et al., [21] suggested that the HA patern of canine parvovirus (CPV) easily altered during natural passages in dogs, and Parrish, et al., [18] showed that only small differences in the capsid protein gene would account for the host range, antigenic type and HA properties. Thus, we suspect that the different pathogenesis of UT-1 strain from the prototype strain of $R V$ may be due to the altered HA pattern and antigenicity [5]. However, the clinical and histopathological findings in the juvenile and newborn rats presented here were essentially consistent with those of other strains of $\mathrm{RV}[2,4,7,11,17]$.

Although antibody production in the infected newborns was slightly delayed to that in the juveniles, the time and level of the peaks of the antibody titer were similar for both (Fig. 1). This fact indicates that the virus propagates at the primary infection sites in juvenilis as well as newborns. Jacoby, et al., [7] showed that the virus was re-isolated from most organs except for brain and blood at 5 to 7 days pi in oronasally inoculated juveniles, and that their viral titer was lower than that in newborns. In our study, the virus was recovered from the lung, spleen and kidneys of juveniles at 15 days pi, but the titer was low. These findings suggest that in juveniles the virus slightly propagates at the primary infection sites and disappears by following antibody production, without evident viremia.

At the same time, we recovered the virus from all the organs tested here including the brain and serum in infected newborns. We also confirmed the evidence for severe viremia with the peak of viral titers at 5 to 10 days pi (Fig. 2 ). Therefore, the virus appeared to propagate remarkably in various organs and caused severe viremia in newborns. Consequently, the antibody produced might block the virus propagation in the organs. Paturzo, et al., [19] reported that $R V$ could be detected in the explanted culture of several organs from infant which were inoculated with the virus 14 weeks before and from juveniles inoculated 7 weeks before, even after seroconversion. In present study, neither the infectious virus nor the viral antigen was detected in any organs of the surviving newborns 4 weeks after inoculation (data not shown). The persistent infections of 
$\mathrm{RV}$ in seroconverted and surviving rats may be detectable by more sensitive assays.

Serological surveys $[6,8,10]$ have shown that specific antibodies were found in the contaminated colonies with $\mathrm{RV}$ at a high incidence up to $100 \%$ and that the virus was maintained for long periods. Therefore, high prevalence of passive immunity in newborn rats could be suspected, which will prevent fatal infection with $R V$, although newborns proved to be highly susceptible to the RV. Then, the natural passages in antibody positive rat colonies during long periods may lead the appearance of variants which are different on some properties such as HA, host range and pathogenicity.

The hepatic lesions, the most overt histopathologic changes in our findings were observed during the later stages of the infection compared to the peak of the viral replication. Distribution of the lesions were not well correlated with that of the antigen. The viral antigen was detected in the apparently normal hepatocytes, but not in the vacuolating or necrotic ones. Thus, these findings suggest that hepatic lesions are due to some secondary mechanism related to the cellular metabolism rather than to direct cell-destruction resulting from viral replication. The different susceptibility of newborns and juveniles to $R V$ infection may also depend on the maturation of the metabolic pathway in the liver.

A part of this work was supported by Expenses for the Special Project Research from Japanese Ministry of Education, Science and Culture.

\section{References}

[1] Baringer, J. R. and Nathanson, N. (1972). Parvovirus hemorrhagic encephalopathy of rats. Lab. Invest., 27, 514-522.

[2] Cole, G. A., Nathanson, N., and Rivet, H. (1970). Viral hemorrhagic encephalopathy of rats. II . Pathogenesis of central nervous system lesions. Am J. Epidemiol, 91, 339-350.

[3] Coleman, G. L., Jacoby, R. O., Bhatt, P. N., Smith, A. L., and Jonas, A. M. (1983). Naturally occurring lethal parvovirus infection of juvenile and youngadult rats. Vet. Pathol, 20, 49-56.

[4] ElDadah, A. H., Nathanson, N., Smith, K. O., Squire, R. A., Santos, G. W., and Melby, E. C. (1967). Viral hemorrhagic encephalopathy of rats. Science, 156 , 392-394.

[5] Fukazawa, T., Sugiyama, Y., and Yagami, K. (1990). Characterization of newly isolated rat viruses from asymptomaticlaboratory rats. Arch Virol, 115, 115121.

[6] Izumi, Y., Fukazawa, T., Sugiyama, Y., Yagami, K., Urano, T., and Tanikawa, T. (1991). The advantage of enzyme-linked immunosorbent assay (ELISA) as a method of microbiologically monitoring for rat virus (RV). Exp. Anim, 40, 367-373.

[7] Jacoby, R. O., Bhatt, P. N., Gaertner, D. J., Smith, A. L. and Johnson, E. A. (1987). The pathogenesis of rat virus infection in infant and juvenile rats after oronasal inoculation. Arch Virol, 95, 251-270.

[8] Kagiyama, N., Takakura, A., and Itoh, T. (1986). A serological survey on 15 murine pathogens in mice and rats. Exp. Anim, 35, 531-536.

[9] Kilham, L. and Ferm, V. H. (1964). Rat virus (RV) infection of pregnant, fetal and newborn rats. Proc. Soc. Exp. Biol Med, 117, 874-879.

[10] Kilham, L. (1965). Viruses of laboratory and wild rats. Nat. Cancer Inst. Monogr., 20, 117-140.

[11] Kilham, L. and Margolis, G. (1966). Spontaneous hepatitis and cerebellar hypoplasia in suckling rats due to congenital infection with rat virus. Am J. Pathol, 49, 457-475.

[12] Kilham, L. and Margolis, G. (1969). Transplacental infection of rats and hamsters induced by oral and parenteral inoculations of $\mathrm{H}-1$ and rat viruses (RV). Teratology, 2, 111-123.

[13] Lipton, H. L. and Johnson, R. T. (1972). The pathogenesis of rat virus infections in the newborn hamster. Lab. Invest., 27, 508-513.

[14] Lipton, H. L., Nathanson, N., and Hodous, J. (1973). Enteric transmission of parvoviruses : pathogenesis of rat virus infection in adult rats. Am J. Epidemiol, 6, 443-446.

[15] Malgolis, G. and Kilham, L. (1970). Parvovirus infections, vascular endothelium, and hemorrhagic encephalopathy. Lab. Invest., 22, 478-488.

[16] Nathanson, N., Cole, G. A., ElDadah, A. H., Santos, G. W., Squire, R. A., and Smith, K. O. (1970) . Viral hemorrhagic encephalopathy of rats. I . Isolation, identification, and properties of the HER strains of rat picodnavirus. Am J. Epide miol, 91, 328-338.

[17] Novotny, J. F. and Hetrick, F. M. (1970). Pathogenesis and transmission of Kilham rat virus infection in rats. Infect. Immun, 2, 298-303.

[18] Parrish, C. R., Aquadro, C. F., and Carmichael, L. E. (1988). Canine host range and a specific epitope map along with variant sequences in the capsid protein gene of canine parvovirus and related feline, mink, and raccoon parvoviruses. Virology, 166, 293-307.

[19] Paturzo, F. X., Jacoby, R. O., Bhatt, P. N., Smith, A. L., Gaertner, D. J., and Ardito, R. B. (1987). Persistence of rat virus in seropositive rats as detected by explant culture. Arch Virol, 95, 137-142.

[20] Reed, L. J. and Muench, H. (1938). A simple method of estimating fifty per cent endopoints. Am J. Hyg., 27, 493-497.

[21] Senda, M., Hirayama, N., Itoh, O., and Yamamoto, H. (1988). Canine parvovirus : Strain difference in hemagglutinination activity and antigenicity. $J$. gen. Virol, 69, 349-354. 
ラットウイルス新分離株の新生仔扣よび

若齢ラットに対する病原性

八神健一・深澤富長・杉山芳宏・藤井敬二*

筑波大学動物実験センター

*筑波大学基礎医学系病理学教室

ラットウイルス新分離株（UT-1株）の新生仔および 若齢ラットに対する病原性を検討した。本ウイルスを脳 内接種した新生仔 (2 日龄) ラットは, 削瘦, 発育不 良, 下㢉, 脱水, 黄㾝を伴 5 全身感染を起こし, 13〜15 日後に死亡した。腹腔内接種した新生仔の症状は, それ より軽度で死亡例も少なかった。いずれの経路から感染 した新生仔も著明なウイルス血症を起こし, 全身の諸蔵 器からウイルスが回収された。病理組織学的には, 肝臓 に肝細胞の空胞化, 壊死が広範囲に認められ, 小脳, 腎 葴, 脾臓にも軽度の病変を認めた。ウイルス抗原は全身
の諸藏器に認められたが, その分布は病変部とは必ずし も一致しなかった。若龄（6週龄）ラットでは, 脳内お よび腹腔内のいずれの経路から接種した場合でも全く症 状を示さず, 組織学的な変化も認められなかったが, 肺, 脾蔵, 腎缄から少量のウイルスが回収され, 抗体の 産生も認められた。これらのことから, ラットウイルス UT-1 株は新生仔ラットに肝病変を伴う致死性感染を起 こし, 若齡ラットには不顕性感染を起こすことが明らか になった。

\section{Explanation of Figures}

Fig. 3A. Vacuolation and necrosis of hepatocytes, and lymphoid cell infiltration in Glisson's sheath. Liver of a newborn rat inoculated ic with the UT-1 strain of RV. Fifteen days after inoculation $\mathrm{H}$-E stain $\times 200$

Fig.3B. Viral antigens were stained brown. Liver of a newborn rat inoculated ic. Fifteen days after inoculation Immuno-peroxidase method $\times 400$

Fig. 3C. Focal hemorrhage in the granular layer. Cerebellum of a newborn rat inoculated ic. Ten days after inoculation H-E stain $\times 200$
Fig. 3D. Viral antigens in the granular layer. Cerebellum of a newborn rat inoculated ic. Ten days after inoculation Immuno-peroxidase method $\times 200$

Fig. 3E. Infiltration of lymphoid cells in subcapsular area. Kidney of a newborn rat inoculated ic. Ten days after inoculation $\mathrm{H}-\mathrm{E}$ stain $\times 200$

Fig. 3F. Viral antigens were stained brown in the epithelial cells of the collecting tubules. Kidney of a newborn rat inoculated ic. Fifteen days after inoculation Immuno-peroxidase method $\times 200$ 

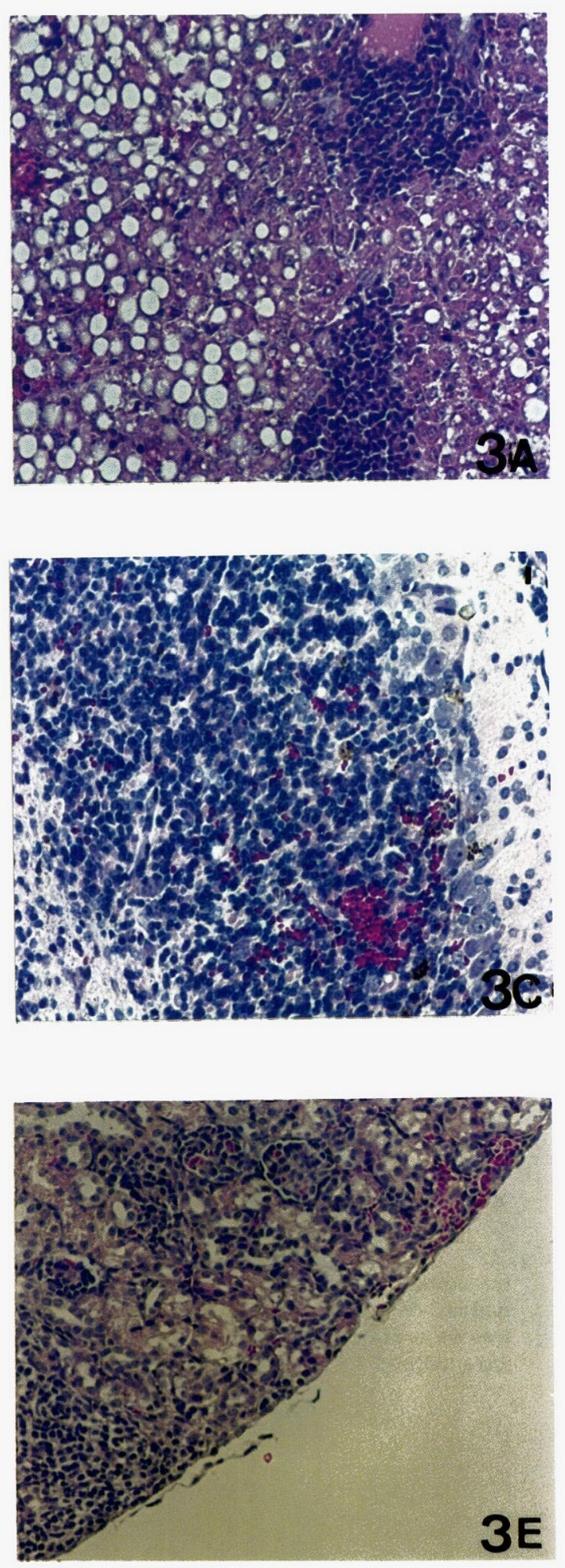
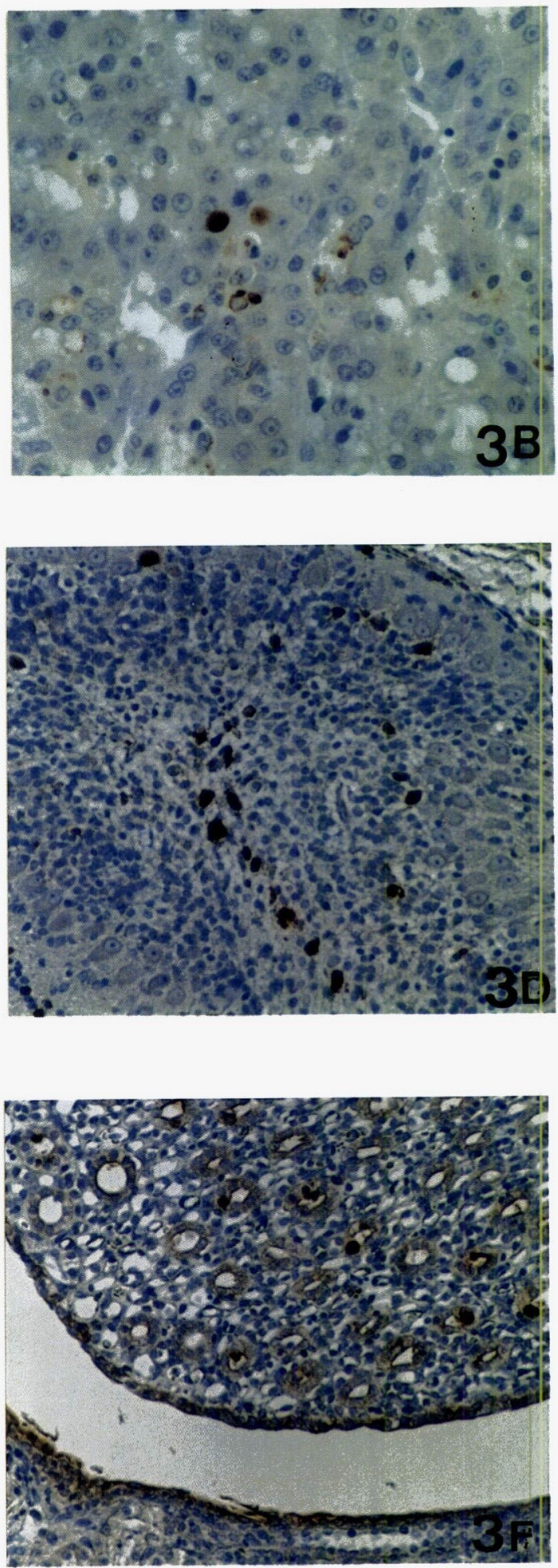